\title{
An online photographic catalog of Platygastroidea (Hymenoptera) in the Institute of Ecology and Biological Resources (Hanoi, Vietnam), with some taxonomic notes
}

\author{
Elijah J. Talamas', Hong-Thai Pham² \\ I Systematic Entomology Laboratory, USDA/ARS clo USNM, Smithsonian Institution, Washington, D. C. 20560, \\ USA 2 Vietnam National Museum of Nature, Vietnam Academy of Science and Technology, Hanoi, Vietnam \\ Corresponding author: Elijah J. Talamas (talamas.1@osu.edu) \\ Academic editor: M. Yoder | Received 17 August 2016 | Accepted 26 April 2017 | Published 21 June 2017 \\ http://zoobank.org/582106B7-D3E7-4ABB-98B9-4DAC81B7F442 \\ Citation: Talamas EJ, Pham H-T (2017) An online photographic catalog of Platygastroidea (Hymenoptera) in the \\ Institute of Ecology and Biological Resources (Hanoi, Vietnam), with some taxonomic notes. In: Talamas EJ, Buffington \\ ML (Eds) Advances in the Systematics of Platygastroidea. Journal of Hymenoptera Research 56: 225-239. https://doi. \\ org/10.3897/jhr.56.10214
}

\begin{abstract}
All holotypes of Platygastroidea housed in the Institute of Ecology and Biological Resources were photographed and these images are now publicly available online, as are images of most species represented in this collection by paratypes alone. Following examination of these specimens, the following taxonomic acts are made: Dyscritobaeus microocellus (Kozlov \& Lê), comb. n. is transferred from Gryon Haliday; Habroteleia dagavia (Kozlov \& Lê), comb. n. is transferred from Triteleia Kieffer; Paridris spinosa Rajmohana, syn. n. and Paridris stigmalshortis Kozlov \& Lê, syn. n. are treated as junior synonyms of Paridris genaris Kozlov \& Lê; Paridris striaefrons Kozlov \& Lê, syn. n. and Paridris circus Kozlov \& Lê, syn. n. are treated as a junior synonyms of Paridris coorgensis Sharma; Probaryconus maridris Kozlov \& Lê, syn. n. and Probaryconus varinus Kozlov \& Lê, syn. n. are treated as junior synonyms of Probaryconus cauverycus Saraswat. A key to the most common species of Paridris in SE Asia is provided.
\end{abstract}

\section{Keywords}

Platygastroidea, taxonomy

Copyright Elijah J.Talamas, Hong-Thai Pham. This is an open access article distributed under the terms of the Creative Commons Attribution License (CC BY 4.0), which permits unrestricted use, distribution, and reproduction in any medium, provided the original author and source are credited. 


\section{Introduction}

The Institute of Ecology and Biological Resources (IEBR), a subdivision of the Vietnam Academy of Science and Technology, houses the holotypes of 178 species described by Lê Xuân Huệ and the late Mikhail Kozlov (formerly of the Zoological Institute of the Russian Academy of Science (ZIN)). Extended-focus images of these holotypes are here made available online to augment the descriptions of Lê and Kozlov and Lê and to establish proper name usage for the Southeast Asian fauna of Platygastroidea. Numerous species have paratypes deposited in IEBR with holotypes deposited in ZIN and we provide images of paratypes for all but three of these species.

In some cases, particularly for very small specimens, the morphology is difficult to interpret due to limitations of the photography system available and the condition of the specimens. Some specimens may eventually require cleaning and photography with more powerful equipment to evaluate all of the characters necessary for species-level identification.

We here make a small number of taxonomic changes for taxa with which we are sufficiently familiar. There are likely to be additional rearrangements to the classification for other species when they are carefully analyzed.

\section{Materials and methods}

The numbers prefixed with "IEBR " or "USNMENT" are unique identifiers for the individual specimens (note the blank space after IEBR). The prefix "IEBR" indicates that the specimen is a holotype, and for these specimens no physical CUID labels were added to the specimens. USNMENT CUID labels were attached to photographed, non-holotype specimens. The data associated with these specimens is deposited in the Hymenoptera Online Database and may be accessed at the following link: purl.oclc. org/NET/hymenoptera/hol, and entering the identifier in the form. Persistent URIs for each taxonomic concept were minted by xBio:D in accordance with best practices recommended by Hagedorn et al (2013). The full list of platygastroid specimens deposited in IEBR and their CUIDs is presented in Suppl. material 1.

Photographs of IEBR specimens were captured with a Canon Rebel 600 camera connected to a Wild M10 microscope with a Fotoprojektiv 2.5x/SLR 10446175 adapter and stacked with the program Zerene Stacker. A scale bar was calibrated for images taken at the maximum magnification of the microscope. Images taken at lower magnifications do not have scale bars. Specimens from the C. A. Triplehorn Collection (OSUC) and the National Insect Collection (USNM) were photographed with a Z16 Leica $^{\text {Фм }}$ lens with a JVC KY-F75U digital camera using Cartograph ${ }^{\text {Фм }}$ or Automontage $^{{ }^{\oplus т}}$ software and stacked with Combine ZP. In some cases, multiple extended-focus images were stitched together in Photoshop to produce larger images at high resolution and magnification. Full resolution images are deposited in the image database at The Ohio State University (specimage.osu.edu) and can be retrieved by either the taxon name or the specimen CUIDs provided in Suppl. material 1. 


\section{Taxonomy}

Dyscritobaeus microocellus Kozlov \& Lê, comb. n. http://bioguid.osu.edu/xbiod_concepts/179794

Figures $1-4$

Gryon microocellus Kozlov \& Lê, 1996: 9 (original description); Lê, 2000: 96, 124 (description, keyed, type information).

Link to distribution map. http://hol.osu.edu/map-large.html?id=179794

Material examined. Holotype, female: VIETNAM: Dak Lak Prov., Crông Buc (Krongbuk), 27.IX.1978, IEBR 0164 (deposited in IEBR).

Comments. We transfer this species from Gryon to Dyscritobaeus based on the location of the lateral ocelli distant from the inner orbits of the eyes, the general shape of the head, the presence of malar striae, and a well-developed occipital carina that is dorsally continuous. The generic concept of Dyscritobaeus somewhat recently was modified by Mineo et al. (2011), who subdivided it into multiple genera based on characters that will likely require reevaluation in the context of the world fauna. However, these issues do not affect our generic transfer of $D$. microocellus, because this species matches their constricted concept of the Dyscritobaeus.

\section{Habroteleia dagavia Kozlov \& Lê, comb. n.}

http://bioguid.osu.edu/xbiod_concepts/28154

Figures $5-10$

Triteleia dagavia Kozlov \& Lê, 1995: 441, 445 (original description, keyed); Kozlov \& Lê, 1996: 9, 14 (described as new, keyed); Lê, 2000: 76, 341 (description, keyed, type information).

Link to distribution map. http://hol.osu.edu/map-large.html?id=28154

Material examined. Holotype, female: VIETNAM: Quang Nam Prov., Lang Stream, forest, Dak Pring, 31.X.1979, X. H. Lê, IEBR 0143 (deposited in IEBR).

Comments. The fore wing is missing from the holotype of $H$. dagavia, precluding examination of its venation, an important character in the key of Chen et al. (2013). We nonetheless are confident in placing this species in Habroteleia Kieffer based on the medially spinose metascutellum and its similarity to $H$. bharatensis Saraswat, with which it may be conspecific. When images of $H$. dagavia were compared to the holotype of $H$. bharatensis, the first author found only a slight variation in the size of the median projection on the propodeum and difference in setation to separate the species. The lack of setation in the holotype of $H$. dagavia may be a preservation artifact, but we consider it prudent not to make a formal decision about the species-level fate of $H$. dagavia without examining more specimens. 


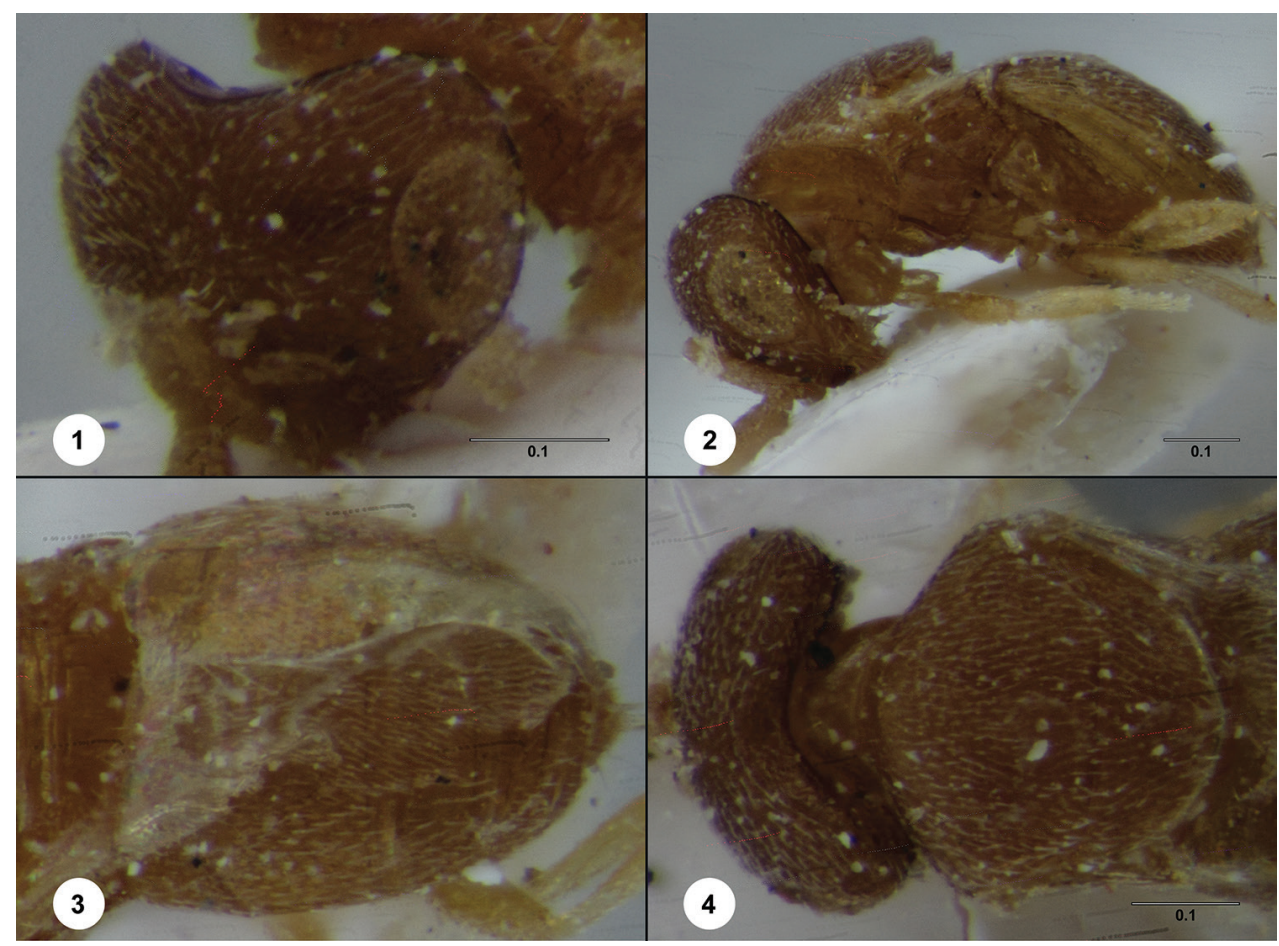

Figures I-4. Dyscritobaeus microocellus, female holotype (IEBR 0164). I head, anterolateral view $\mathbf{2}$ head, mesosoma, metasoma, lateral view $\mathbf{3}$ metasoma, dorsal view $\mathbf{4}$ head and mesosoma, dorsal view. Scale bars in millimeters.

\section{Paridris coorgensis Sharma}

http://bioguid.osu.edu/xbiod_concepts/5065

Figures 11-25

Paridris coorgensis Sharma, 1978: 26 (original description); Mani \& Sharma, 1982: 177

(description); Johnson, 1992: 458 (cataloged); Rajmohana K., 2007: 57 (keyed). Paridris circus Kozlov \& Lê syn. n., 2000: 65, 66, 336 (original description, keyed). Paridris striaefrons Kozlov \& Lê syn. n., 2000: 65, 71, 339 (original description, keyed).

Link to distribution map. http://hol.osu.edu/map-large.html?id=5065

Material examined. Paridris coorgensis, holotype female: INDIA: Karnataka St., Madikeri, Appangala, 9.III.1975, M. S. Mani, USNMENT01197117 (deposited in USNM). Paridris circus, holotype female: VIETNAM: Gia Lai Prov., K'Bang Dist., Buôn Lưới, 25.XI.1978, IEBR 0106 (deposited in IEBR). Paridris striaefrons, holotype male: VIETNAM: Gia Lai Prov., K’Bang Dist., Buôn Lưới, 7.VII.1981, IEBR 0103 (deposited in IEBR). Other material: (18 females, 14 males, 1 unsexed) LAOS: 4 females, 4 males, 1 unknown, OSUC 262201-262209 (CNCI). THAILAND: 11 


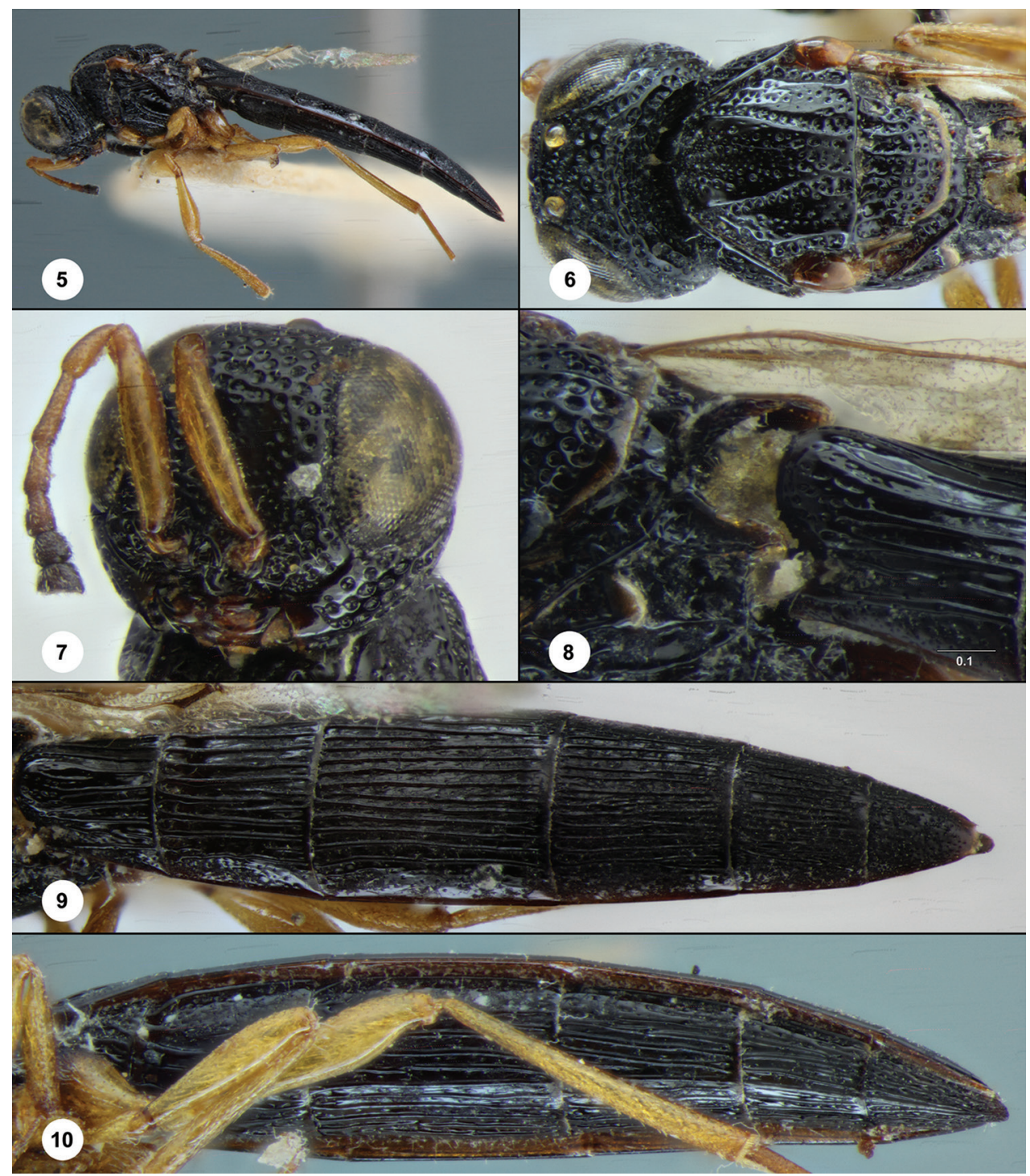

Figures 5-10. Habroteleia dagavia, female holotype (IEBR 0143). 5 head, mesosoma, metasoma, lateral view $\mathbf{6}$ head and mesosoma, dorsal view $\mathbf{7}$ head, anterior view 8 mesoscutellum, metascutellum, propodeum, T1, dorsolateral view $\mathbf{9}$ metasoma, dorsal view $\mathbf{1 0}$ metasoma, ventrolateral view. Scale bars in millimeters.

females, 6 males, OSUC 262236 (CNCI); OSUC 225460-225464, 237420, 266167, 266170-266172, 266176-266178, 381815, 404961, 405076 (OSUC). VIETNAM: 3 females, 4 males, OSUC 265231, 265233 (RMNH); OSUC 261907, 266160266162 (ROME); USNMENT01223722 (USNM). 


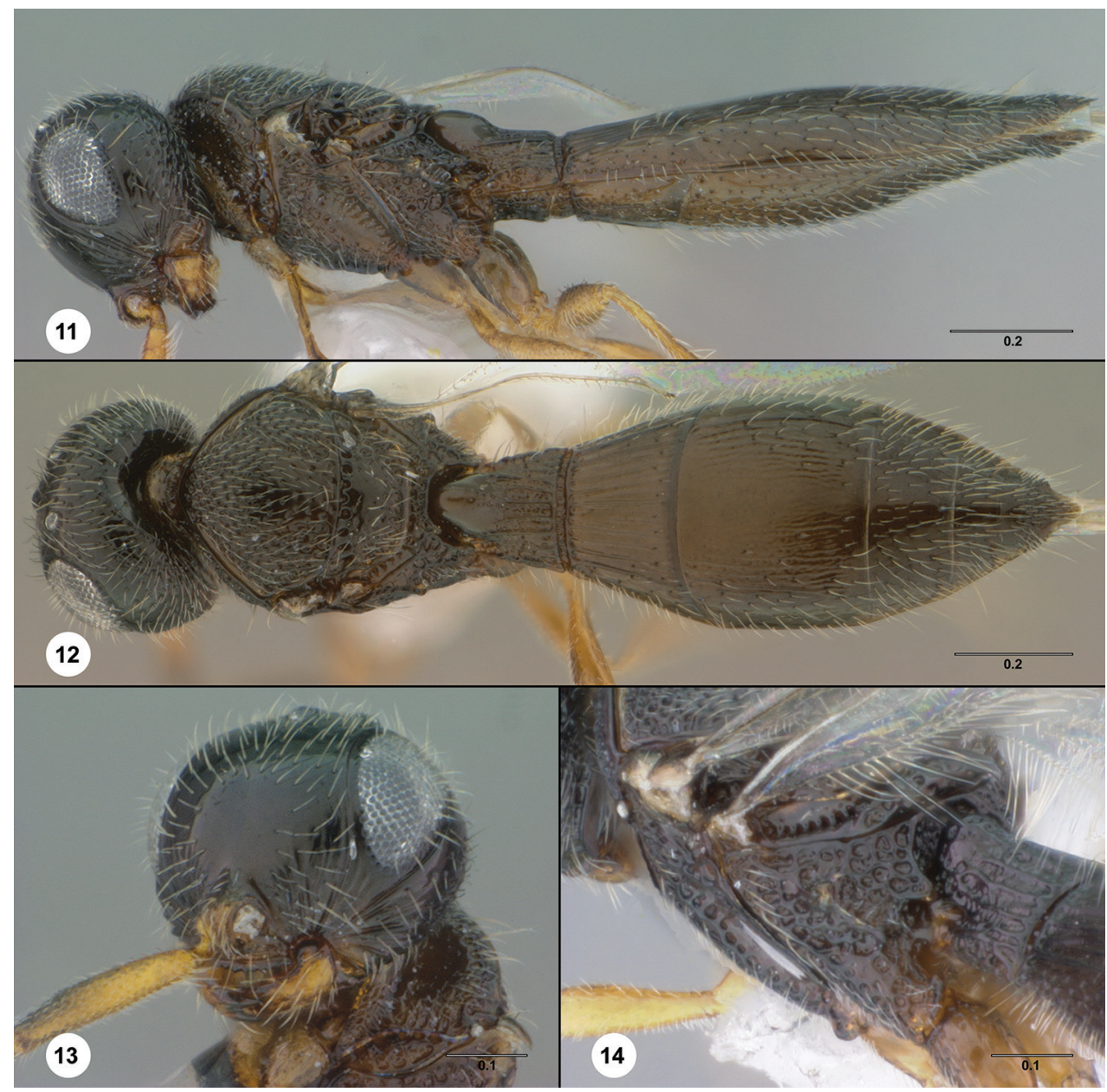

Figures II-I4. Paridris coorgensis II female (USNMENT01223722), head, mesosoma, metasoma, lateral view $\mathbf{I} \mathbf{2}$ female (USNMENT01223722), head, mesosoma, metasoma, dorsal view $\mathbf{I}$ female (USNMENT01223722), head, anterolateral view 14 female (OSUC 266171), metascutellum, propodeum, T1, posterolateral view. Scale bars in millimeters.

Comments. The holotype of Paridris coorgensis does not have a posteriorly directed spine on the horn of T1 (Figure 17), the metascutellum is bispinose (Figure 16), and T6 is constricted apically (Figure 18). These characters are diagnostic for this species and can be more clearly seen in a Figures 11-14 which illustrate well preserved specimens. Paridris asian sp. 1 in the phylogeny of Talamas et al. (2013) is here identified as Paridris coorgensis. 


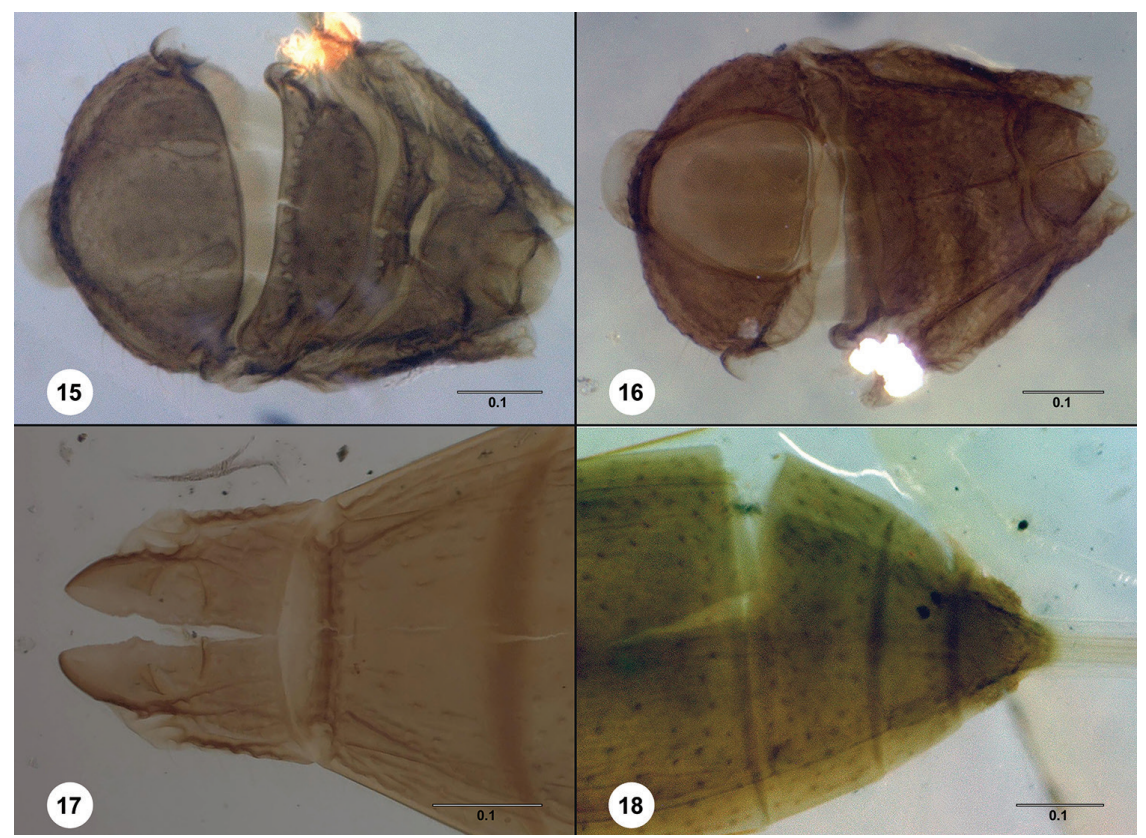

Figures I5-18. Paridris coorgensis, holotype female (USNMENT01197117). I5 mesosoma, dorsal view 16 mesosoma, ventral view 17 T1-T2, dorsal view 18, T3-T6, dorsal view. Scale bars in millimeters.

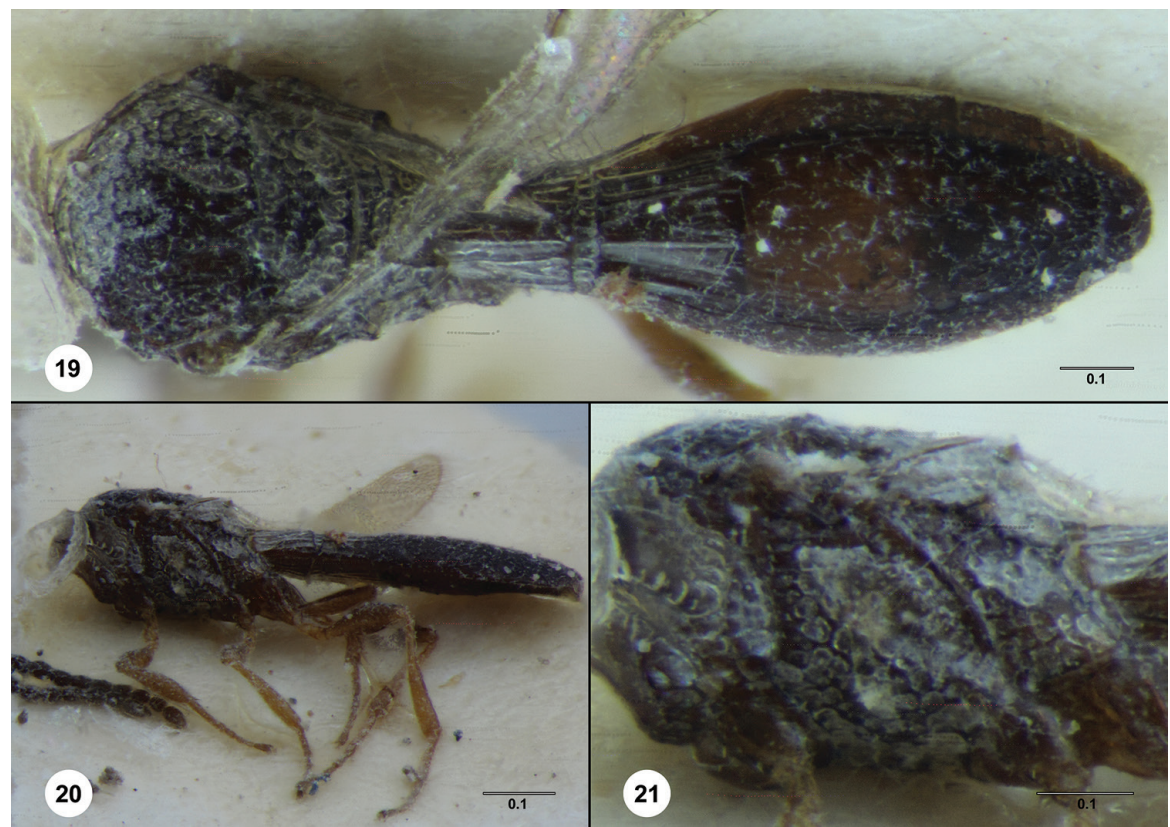

Figures I 9-2 I. Paridris striaefrons (=Paridris coorgensis), male holotype (IEBR 0103). 19 mesosoma and metasoma, dorsal view $\mathbf{2 0}$ antennae, mesosoma, metasoma, lateral view $\mathbf{2} \mathbf{I}$ mesosoma, lateral view. Scale bars in millimeters. 


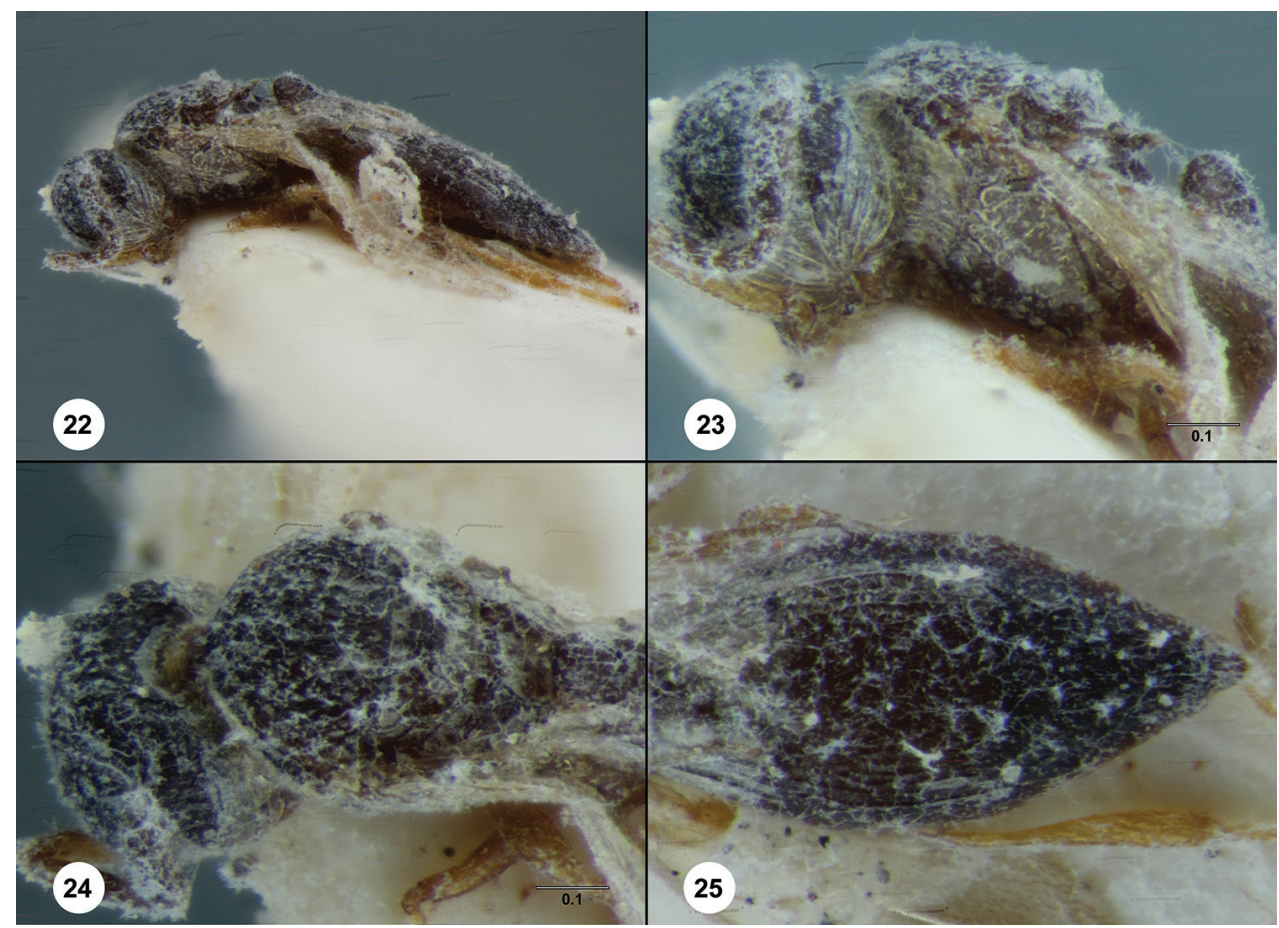

Figures 22-25. Paridris circus (=Paridris coorgensis), female holotype (IEBR 0106). 22 head, mesosoma, metasoma, lateral view $\mathbf{2 3}$ head, mesosoma, T1, lateral view $\mathbf{2 4}$ head and mesosoma, dorsal view 25 metasoma, dorsal view. Scale bars in millimeters.

\section{Paridris genaris Kozlov \& Lê}

http://bioguid.osu.edu/xbiod_concepts/179768

Figures 26-37

Paridris genaris Kozlov \& Lê, 2000: 65, 67, 337 (original description, keyed)

Paridris stigmalshortis Kozlov \& Lê syn. n., 2000: 65, 70, 338 (original description, keyed). Paridris spinosus Rajmohana, 2011: 9 (original description).

Paridris spinosa Rajmohana syn. n.: Talamas, Masner \& Johnson, 2012: 32 (gender emended).

Link to distribution map. http://hol.osu.edu/map-large.html?id=179768

Material examined. Holotype, female: VIETNAM: Gia Lai Prov., An Khe, Tân Tạo, 24.XI.1978, X. H. Lê, IEBR 0105 (deposited in IEBR). Paridris spinosus, holotype female (examined via photographs), INDIA: Kerala: Palghat (Pudunagaram), 1-I-2011, Bijoy, ZSIC/WGRS/G4 (deposited in ZSIC). Paridris stigmalshortis, holotype female: VIETNAM: Dac Lac Prov., 19.IX.1978, X. H. Lê, IEBR 0107 (deposited in IEBR). Other material: INDIA: 1 female, OSUC 404966 (USNM). 


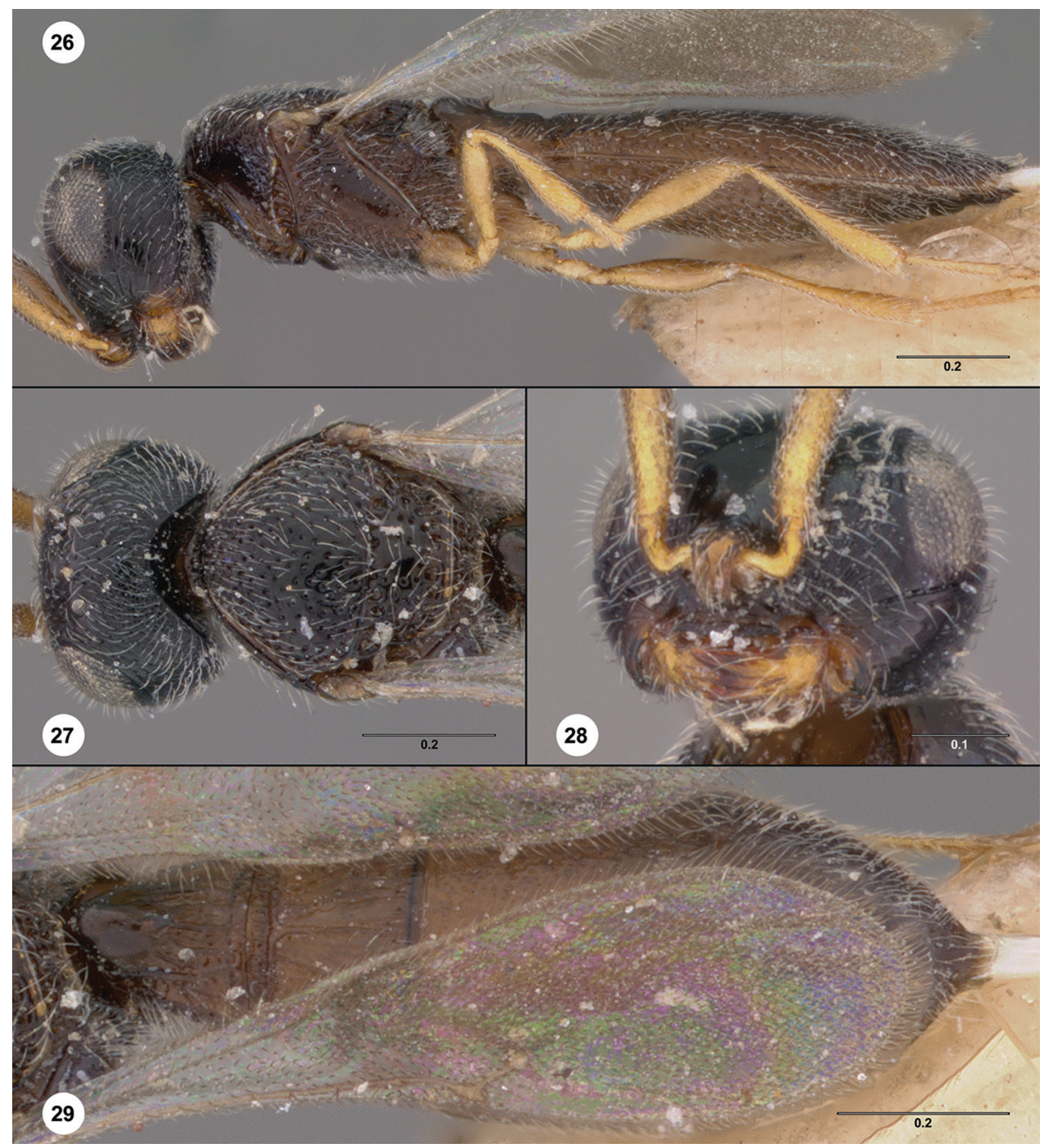

Figures 26-29. Paridris genaris, female (OSUC 404966). 26 head, mesosoma, metasoma, lateral view $\mathbf{2 7}$ head and mesosoma, dorsal view $\mathbf{2 8}$ head, anterolateral view $\mathbf{2 9}$ metasoma, dorsal view. Scale bars in millimeters.

Comments. Paridris genaris is a distinctive species. The combination of the setose metascutellum (Figure 27), posteriorly directed spine on the horn of T1 (Figure 26), and T6 with smoothly convex lateral margins (Figure 29) separate it from Paridris bispores and P. coorgensis and are the basis for treating P. spinosus as a junior synonym. 


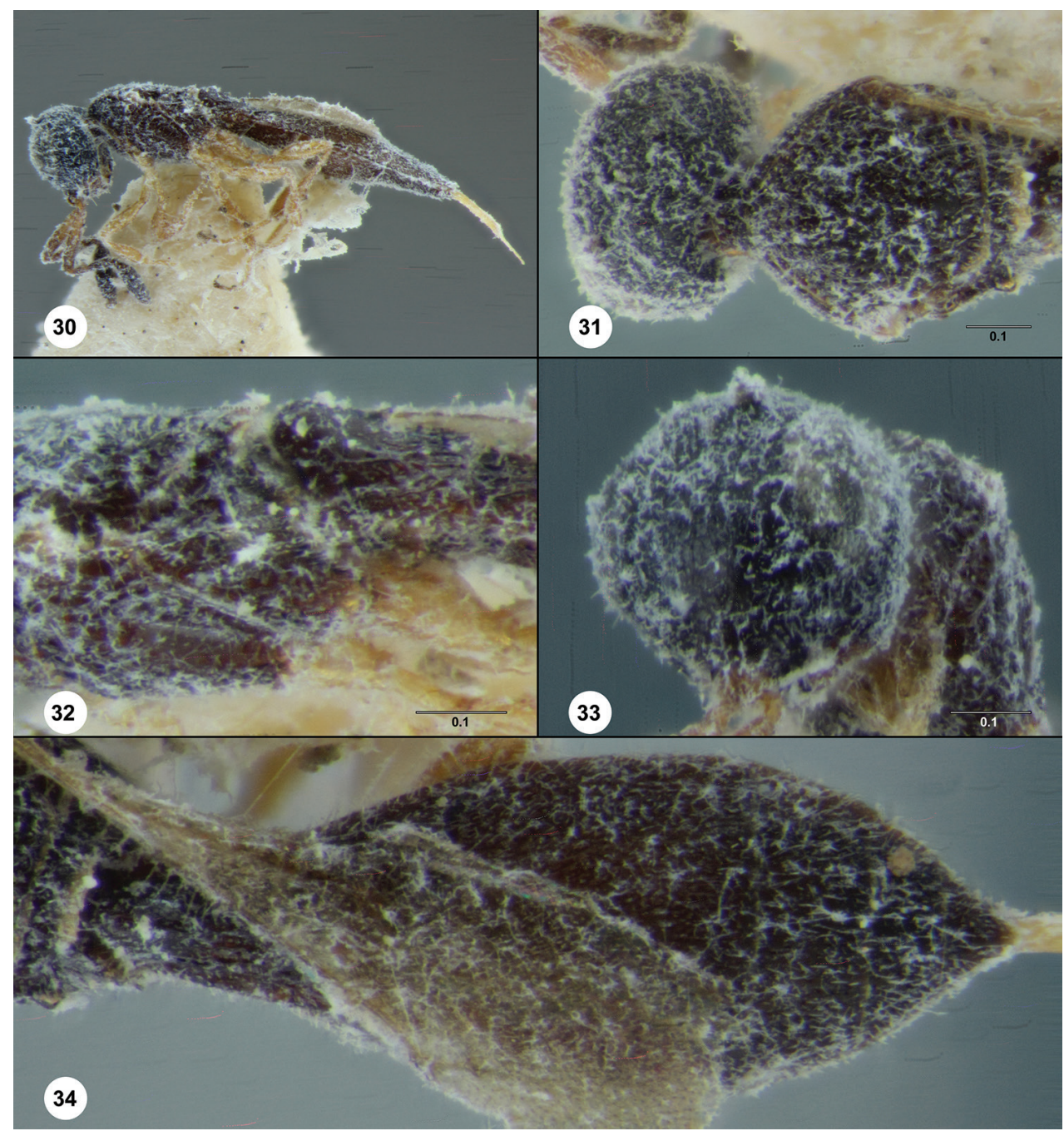

Figures 30-34. Paridris genaris, female holotype (IEBR 0105). 30 head, mesosoma, metasoma, lateral view $\mathbf{3} \mathbf{I}$ head and mesosoma, dorsal view $\mathbf{3 2}$ mesosoma and T1, dorsolateral view $\mathbf{3 3}$ head, anterolateral view $\mathbf{3 4}$ metasoma, dorsal view. Scale bars in millimeters.

\section{Comments on Paridris in SE Asia}

Outside of the nephta group, the three most common species of Paridris in Southeast Asian are $P$. bispores, $P$. coorgensis, and $P$. genaris and each of these has been described multiple times, sometimes by the same author. Taxonomy of Paridris in Southeast Asia has generally been a confused affair primarily because the genus was not well-delimited until relatively recently (Talamas et al. 2013) and primary types were not accessible. 


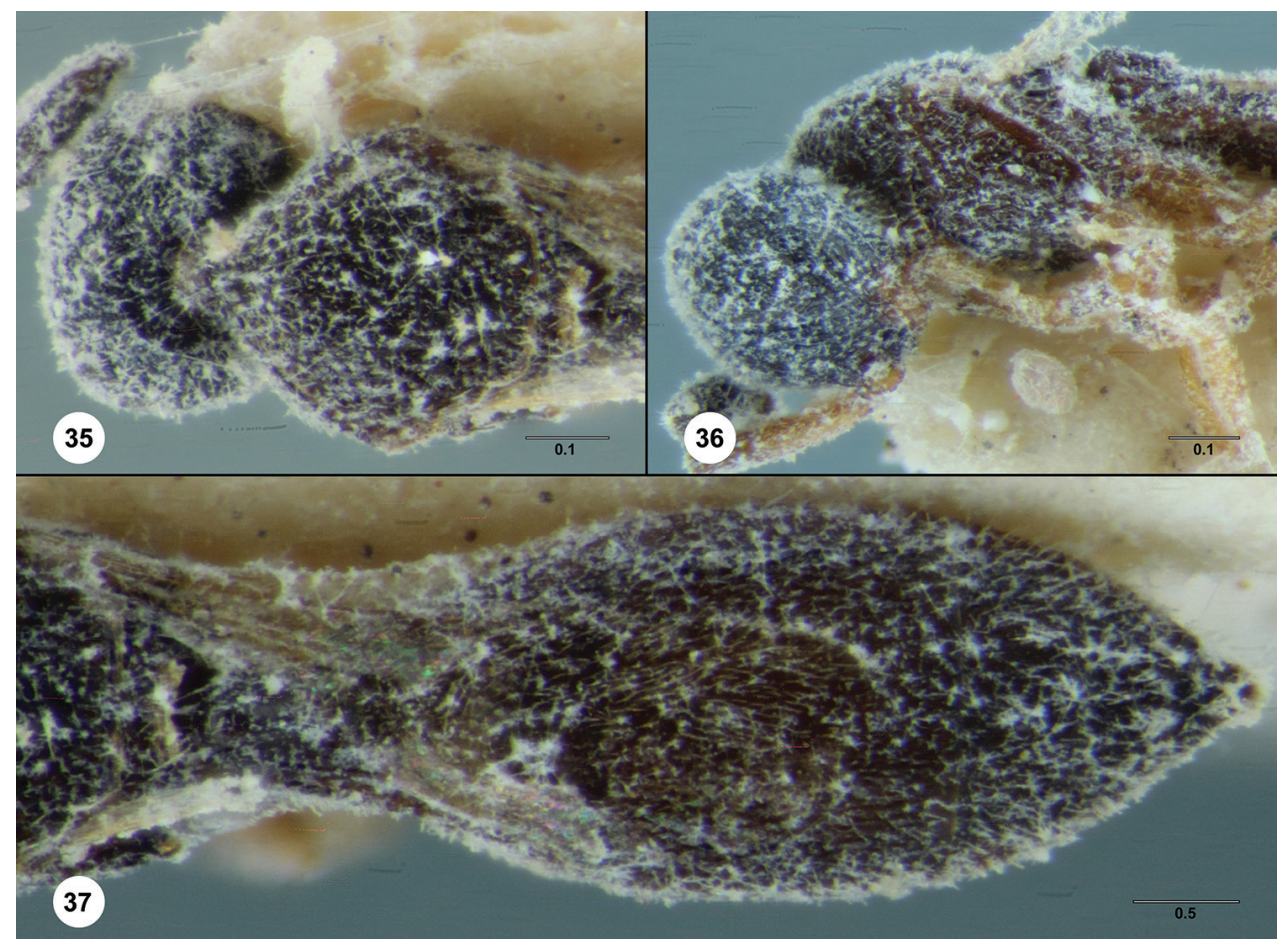

Figures 35-37. Paridris stigmalshortis (=Paridris genaris), female holotype (IEBR 0107). 35 head and mesosoma, dorsal view $\mathbf{3 6}$ head and mesosoma, lateral view $\mathbf{3 7}$ metasoma, dorsal view. Scale bars in millimeters.

Multiple species of Paridris Kieffer have now been transferred to other genera (Talamas et al. 2017) and we suspect that Paridris dunensis Mukerjee is a junior synonym of Probaryconus cauverycus based on Mukerjee's 1994 description, but prefer not to make the generic transfer until the specimen is examined. To clarify the characters that separate P. bispores, P. coorgensis, and P. genaris, we provide the following key to females:

$1 \quad$ Metascutellum without setae and with posterior margin strongly emarginate (Figure 12); T6 distinctly constricted apically (Figure 12)

Paridris coorgensis Sharma

- $\quad$ Metascutellum setose and with posterior margin straight; T6 without distinct

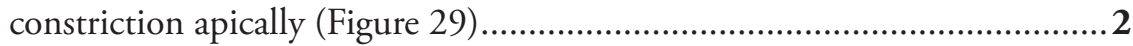

2 Horn of T1 with posteriorly directed spine (Figure 26)

Paridris genaris Kozlov \& Lê

- $\quad$ Horn of T1 without spine (as in Figures 11, 14) 

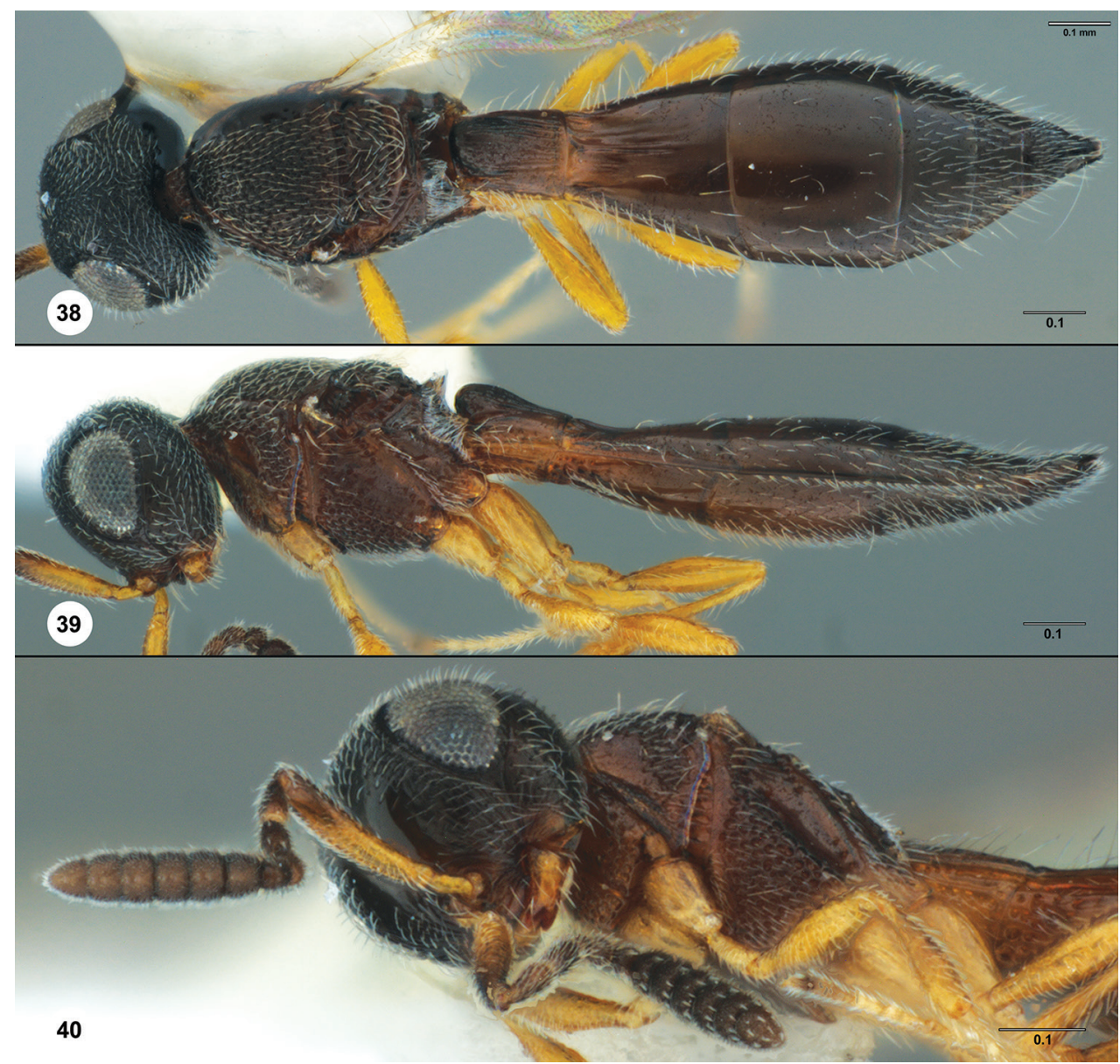

Figures 38-40. Probaryconus cavverycus, female (USNMENT01223894). 38 head, mesosoma, metasoma, dorsal view $\mathbf{3 9}$ head, mesosoma, metasoma, lateral view $\mathbf{4 0}$ head, mesosoma, ventrolateral view. Scale bars in millimeters.

\section{Probaryconus cauverycus Saraswat}

http://bioguid.osu.edu/xbiod_concepts/5096

Figures 38-44

Probaryconus cauverycus Saraswat, 1978: 22 (original description); Mani \& Sharma, 1982: 176 (description); Johnson, 1992: 463 (cataloged).

Probaryconus maridris Kozlov \& Lê syn. n., 2000: 73, 339 (original description, keyed). Probaryconus varinus Kozlov \& Lê syn. n., 2000: 72, 74, 340 (original description, keyed).

Link to distribution map. http://hol.osu.edu/map-large.html?id=5096 


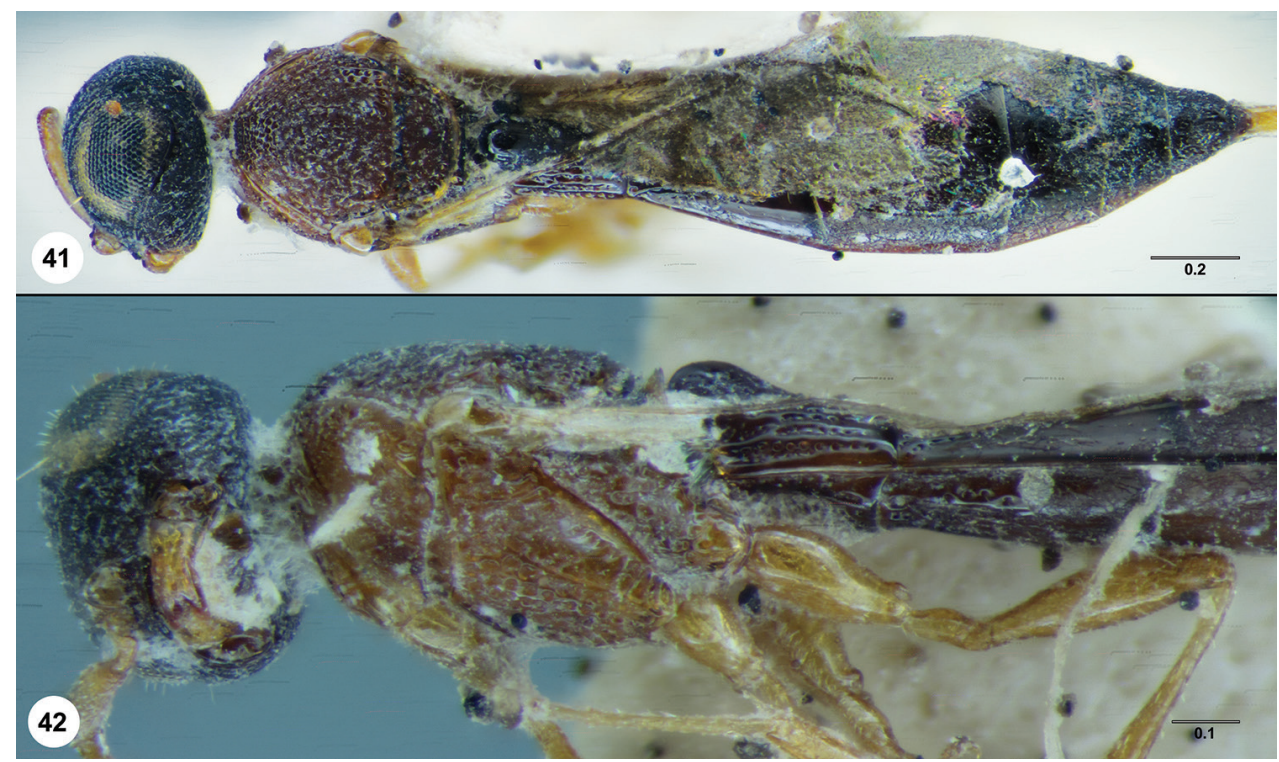

Figures 4I-42. Probaryconus maridris (=Probaryconus cavverycus), female holotype (IEBR 0130). $4 \mathbf{I}$ head, mesosoma, metasoma, dorsal view $\mathbf{4 2}$ head, mesosoma, metasoma, lateral view. Scale bars in millimeters.

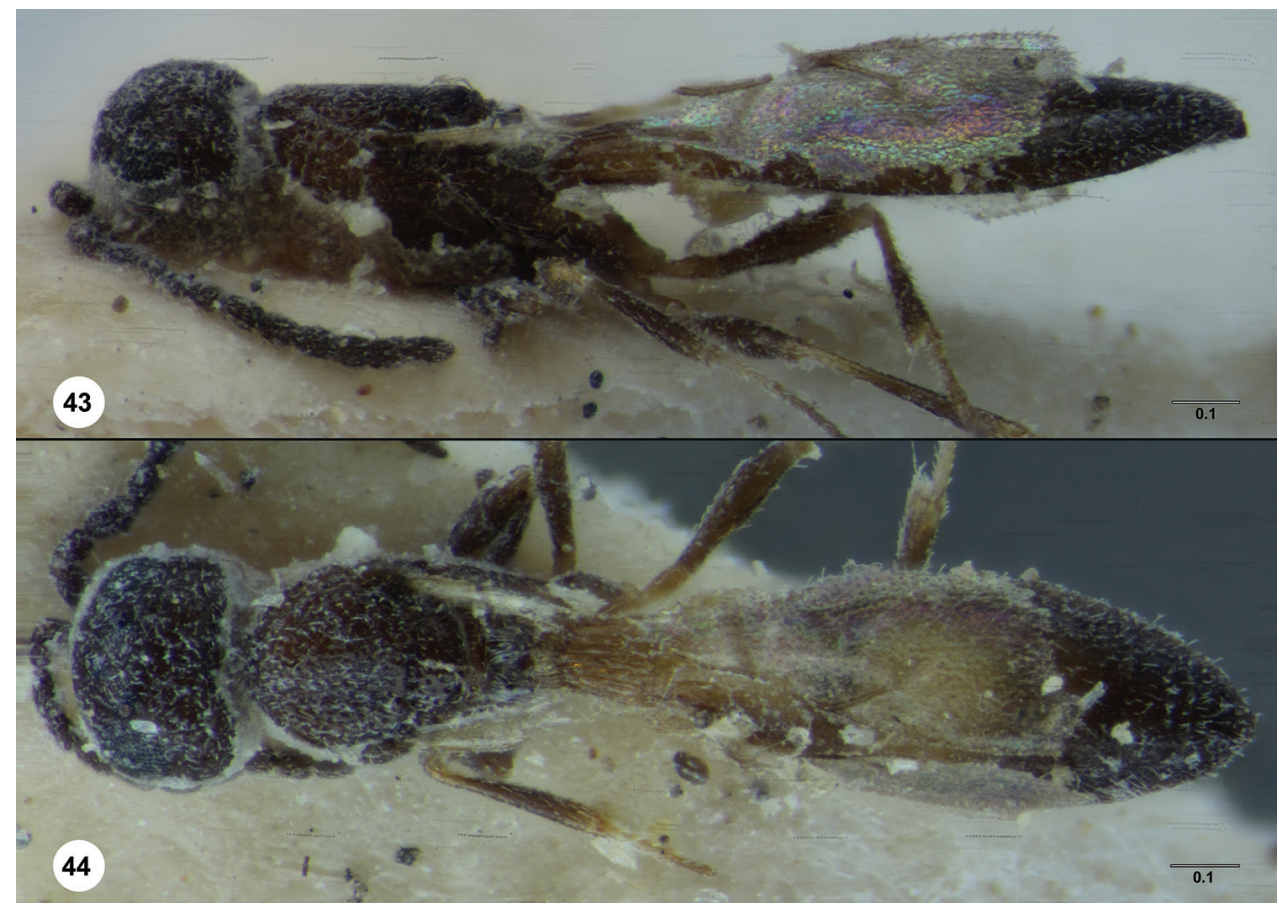

Figures 43-44. Probaryconus varinus (=Probaryconus cauverycus), male holotype (IEBR 0132). 43 head, mesosoma, metasoma, lateral view $\mathbf{4 4}$ head, mesosoma, metasoma, dorsal view. Scale bars in millimeters. 
Material examined. Probaryconus cauverycus, holotype female: INDIA: Karnataka St., Tala Kaveri, 10.III.1975, M. S. Mani, USNMENT01109607 (deposited in USNM). Probaryconus maridris, holotype female: VIETNAM: Hoa Binh Prov., forest edge, Thuong Tien, 29.X.1978, X. H. Lê, IEBR 0130 (deposited in IEBR). Probaryconus varinus, holotype male: VIETNAM: Phu Yen Prov., Krong Trai (Suoi Trai Tay Son) Nature Reserve, 29.III.1983, X. H. Lê, IEBR 0132 (deposited in IEBR). Other material: THAILAND: 1 female, USNMENT01223894.

Comments. Paridris cauverycus is known to us from multiple localities in Southeast Asia and exhibits a moderate degree of variability in color of the mesosoma, ranging from brown to orange. Sexual dimorphism occurs in the coloration of the metasoma, with tergites 1-3 pale in males and brown in females. Apart from these variations in color, we found no characters to separate Probaryconus cauverycus, $P$. maridris, and $P$. varinus.

\section{Acknowledgments}

We extend our gratitude to Norman Johnson (OSUC) for developing and maintaining the Hymenoptera Online Database, Specimage, and vSysLab, which underlie the cybertaxonomy conducted here. The camera for this project was generously provided by Andrea Arzaba, and the lens adaptor by Jonathan Coddington (USNM). Tran Thi Men provided valuable assistance to the first author through his visit to Hanoi. This study would not have been possible without the help of Dr. Pham Thi Nhi (Institute of Ecology and Biological Resources, Hanoi), who kindly allowed access to the IEBR collection. This work was made possible by funding from the Systematic Entomology Laboratory, the Beneficial Insect Introduction Research Unit and the National Institute of Food and Agriculture-Specialty Crop Research Initiative (USDA-NIFASCRI) \#2011-51181-30937.. The USDA does not endorse any commercial product mentioned in this research. USDA is an equal opportunity provider and employer.

\section{References}

Hagedorn G, Catapano T, Güntsch A, Mietchen D, Endresen D, Sierra S, Groom Q, Biserkov J, Glöckler F, Morris R (2013) Best practices for stable URIs.

Johnson NF (1992) Catalog of world Proctotrupoidea excluding Platygastridae. Memoirs of the American Entomological Institute 51: 1-825. https://doi.org/10.5281/zenodo.23657

Kozlov MA, Lê X-H (1995) [New species of the genus Triteleia Kieffer, 1906 (Hymenoptera, Scelionidae) of the fauna of Vietnam]. Entomologicheskoye Obozreniye 74(2): 441-446. Kozlov MA, Lê X-H (1996) New species of the genus Triteleia Kieffer, 1906 (Hymenoptera, Scelionidae) of the fauna of Vietnam. Entomological Review 75(8): 9-14. https://doi. org/10.5281/zenodo. 24517 
Lê X-H (1996) Khóa phân loại các loài thuộc giốg Gryon Haliday, 1833 (Hymenoptera: Scelionidae) ở Việt Nam. [Key to egg-parasites of genus Gryon Haliday, 1833 (Hymenoptera: Scelionidae) from Viet Name. Tap chi Bao ve Thuc vat 5: 9-15.

Lê X-H (2000) Egg-parasites of family Scelionidae (Hymenoptera). Fauna of Vietnam, vol. 3. Science and Technics Publishing House, Hanoi, 386 pp.

Mani MS, Sharma SK (1982) Proctotrupoidea (Hymenoptera) from India. A review. Oriental Insects 16: 135-258. https://doi.org/10.5281/zenodo.23658

Mukerjee MK (1994) Descriptions of some new and records of some known Proctotrupoidea (Hymenoptera) from Garhwal Himalayas, India. Records of the Zoological Survey of India Occasional Papers 163: 1-73. https://doi.org/10.5281/zenodo.24529

Rajmohana K (2007) Fauna of the Kudremukh National Park. Insecta: Scelionidae (Platygastroidea): Hymenoptera. Conservation Area Series 32: 49-69.

Rajmohana K, Bijoy C (2011) A new species of Paridris Kieffer (Hymenoptera: Platygastridae) from India. Hexapoda 18(1): 9-12.

Saraswat GG, Sharma SK (1978) On some Scelionidae (Hymenoptera: Proctotrupoidea) from India. Memoirs of the School of Entomology, St. John's College 5: 1-46. https://doi. org/10.5281/zenodo. 23677

Talamas EJ, Masner L, Johnson NF (2011) Revision of the Paridris nephta species group (Hymenoptera, Platygastroidea, Platygastridae). ZooKeys 133: 49-94.

Talamas EJ, Masner L, Johnson NF (2013) Systematics of Trichoteleia Kieffer and Paridris Kieffer (Hymenoptera, Platygastroidea, Platygastridae). Journal of Hymenoptera Research, 34: 1-79. https://doi.org/10.3897/jhr.34.4714

\section{Supplementary material I}

\section{Platygastroidea in IEBR}

Authors: Elijah J. Talamas, Hong-Thai Pham

Data type: species data

Explanation note: A table lists the species of Platygastroidea, the author of the species, how many specimens are present in IEBR, including type status, and collecting unit identifiers for specimens that have been photographed.

Copyright notice: This dataset is made available under the Open Database License (http://opendatacommons.org/licenses/odbl/1.0/). The Open Database License $(\mathrm{ODbL})$ is a license agreement intended to allow users to freely share, modify, and use this Dataset while maintaining this same freedom for others, provided that the original source and author(s) are credited. 